\title{
Kirjallisuuden(tutkimuksen) kuvitteluvoima
}

Amerikkalaisen Neal Stephensonin post-apokalyptinen romaani seveneves (2015) alkaa tehokkaasti toteamalla, että kuu on räjähtänyt varoittamatta ja ilman selvää syytä. Melkein 900-sivuisessa romaanissa kuvataan erilaisia strategioita ja yrityksiä selvitä räjähdyksestä, joka merkitsee maapallon tuhoa ja kaiken elämän päättymistä.

Romaanin kolmas osa alkaa sanoilla "Five thousand years later." Virkkeeseen tiivistyy monta asiaa. Tämä ilmoitus, "viisi tuhatta vuotta myöhemmin", ei kerro pelkästään kirjallisuuden kyvystä hypätä ajallisesti ja tilallisesti toisiin maailmoihin ja todellisuuksiin. Se kertoo myös siitä, että kirjallisuudessa ja taiteissa voidaan kuvitella tulevaisuuksia myös tilanteissa, joissa maapallo tuhoutuu.

Kirjallisuudentutkijain Seuran ja Kulttuurintutkimuksen Seuran yhteisessä "Ympäristöt"-seminaarissa Jyväskylän yliopistossa (22.-23.5.2017) sen sijaan kuultiin myös sellaisia puheenvuoroja, joissa ei enää nähty tulevaisuutta. Kyky luottaa ihmiseen on kadonnut ihmisen toiminnan ja tekojen vuoksi: elämme ympäristökriisien aikaa, peruuttamattomien globaalien muutosten aikaa. Saattoipa joku kirjallisuudentutkija puuskahtaa turhautumisensa tekstien tutkimiseen näinä aikoina, jolloin "oikean elämän ongelmat” puskevat päälle.

Alistuneiden ja turhautuneiden äänien rinnalla "Ympäristöt"-tapahtumassa kuului kovempana kuitenkin kirjallisuuden- ja kulttuurintutkijoiden usko oman alansa mielekkyyteen toimintana, joka voi omalta osaltaan muuttaa maailmaa ainakin kiinnittämällä huomiota moninaisten ympäristöjen ongelmiin ja kytkeytymisiin. Kirjallisuuden kuvitteluvoima siirtyy parhaimmillaan kirjallisuudentutkijoiden tapoihin tarkastella, problematisoida ja myös kuvitella mahdollisia tulevaisuuksia niin tutkimukselle itselleen kuin maailmalle. Jo seminaarin mahdollistama tapa hahmottaa ympäristöiksi mitä monenlaisimpia alueita vaikkapa luontokulttuureista käsiteympäristöihin ja äänimaailmoista tekstiympäristöihin kertoo moninaisuudesta, josta soisi syntyvän uusia ajattelupintoja myös tutkimusmaailman ulkopuolella oleville ihmisille. Eri taiteiden tutkijat ovat asiantuntijoita juuri suhteessa kuviteltuihin maailmoihin, todellisuuksiin ja tulevaisuuksiin. Kuvitelmat voivat muuttua todeksi - niin hyvässä kuin pahassa.

Avaimen tämän numeron artikkeleissa Juri Joensuu käsittelee kuvitteellisia reseptejä ja mielikuvituksellisia keitoksia niin suomalaisessa kuin kansainvälisessä kirjallisuudessa. Osaa artikkelin ruokalajeista tai ohjeista ei oikeasti voisi edes toteuttaa, mutta niiden kuvitteleminen on silti mahdollista. Mahdottoman rajoilla liikkuvat reseptit inspiroivat katsomaan maailmaa totutusta poikkeavilla tavoilla - milloin kriittisesti, milloin taas huumorin kautta. Lena Gottelier puolestaan keskittyy suomalaiseen etnofuturistiseen 
nykylyriikkaan, jossa menneen ajan perinteitä tuodaan nykyhetkeen tulevaisuuteen viittaavalla tavalla. Runoissa kierrätetään kansanperinteestä tuttua mutta jo unohtumassa olevaa kieltä, ja tässä kielten ja kulttuurien monimuotoisuuden ajatus on tärkeä. Runot houkuttelevat myös nykyistä läheisempään luontosuhteeseen, josta ihminen on erkaantunut modernisoitumisen myötä.

Elsi Hyttinen tarkastelee Leea ja Klaus Klemolan Maaseudun tulevaisuus -näytelmää (2014) kirjoittamalla nykyisestä antroposeenin ajasta interregnumina eli murroskautena, jossa niin sanottu vanha valta on siirtymässä pois uuden alta. Hyttinen pohtii kirjallisuudentutkimuksen epistemologisia valintoja osoituksena alalla vaikuttavasta interregnumista samalla kun hän osoittaa Klemoloitten näytelmän kommentoivan erityisesti antroposeenin ajalle ominaisia ihmisen ja ei-inhimillisen välisiä suhteita. Viimeisessä artikkelissa Kati Kanto tutkii Anna-Liisa Haakanan nuortenkirjoja tilallisuuden kautta: pohjoista Suomea kuvaavissa kirjoissa nuoret päähenkilöt kokevat pohjoisen alueen tilat ja paikat milloin voimaannuttavina, milloin ahdistavina.

Kirjallisuusoppiaineita esittelevän kirjoitussarjan päättävät Helsingin yliopiston Kotimainen kirjallisuus ja Nordisk litteratur. Hannu K. Riikosen arvostelun kohteina ovat Markku Eskelisen Raukoilla rajoilla. Suomenkielisen proosakirjallisuuden historiaa -teos (2016) sekä Yrjö Varpion muistelmateos Tämä on vielä kerrottava. Elämää yliopistomaailmassa ja kirjailijoiden parissa (2016). Jani Ylönen puolestaan arvioi The Cambridge Companion to Literature and the Posthuman -teoksen (2016).

Kuvitteluvoimaista kesää toivottaen

Kaisa Kurikka ja Anna Helle 